\title{
SHAOLIN KUNG FU/WUSHU - SKARB NARODU CHIŃSKIEGO
}

Historia sztuk walki Państwa Środka jest równie burzliwa i ciekawa jak dzieje samych Chin. Niejednokrotnie odgrywały one kluczową rolę w wielu przełomowych momentach. Tak zwane tradycyjne style walki, głównie rodzinne, przekazywane były jedynie w wąskim gronie zaufanych osób. Był to pilnie strzeżony sekret niczym najdroższy skarb. Z uwagi na takie podejście wiele technik przepadło, a rewolucja kulturalna niemal doprowadziła do ich zlikwidowania.

\section{Skrócony rys historyczny}

„Całe kung fu powstało w słońcu klasztoru Shaolin” - w ten sposób tłumaczono powstanie chińskich sztuk walki. Wynika z tego również, że kolebką kung fu jest wspomniana świątynia buddyjska. Na temat samej sztuki walki i miejsca jej stworzenia powstała niezliczona ilość legend i opowieści. Właściwie w każdej z nich pojawia się osoba Bodhidharmy, hinduskiego mnicha znanego również jako Da Mo. Jest on prekursorem buddyjskiej sekty Mahajana - buddyzmu chan (jap. zen).

W paśmie górskim Songshan znajdują się dwa szczyty: Taishi i Shaoshi, które otaczają klasztor Shaolin (w j. chiń. Shaolin oznacza Młody Las). Pierwszy człon nazwy świątyni Młodego Lasu pochodzi od drugiego szczytu (shao- młody), zaś drugi odwołuje się do tego, że znajduje się on w lesie (lin). Klasztor został zbudowany za panowania północnej dynastii Wei (386-534) w 495 r. z polecenia cesarza Wendi. Był to dom dla mnicha imieniem Ba Tuo, który przybył do Chin, aby szerzyć buddym Hinajana 30 lat przed wspomnianym wcześniej Bodhidharmą. Jedna z legend o hinduskim mnichu mówi, że przez 9 lat medytował w pozycji siedzącej, z twarzą zwróconą do skały. Opuścił swoją samotnię dopiero wówczas, gdy zdał sobie sprawę, że „należy utrzymać spokój emocjonalny w symbiozie z ruchem, a kontrolować ruch z emocjonalnym spokojem. Spokój i ruch uzupełniają się i czerpią z siebie wzajemnie korzyści"'. Do tej pory w samej świątyni pokazywany jest kamień z jego

1 Lu Hongjun, Yang Hui, Li Chunsheng, Chinese Shaolin Kung Fu, Beijing 2007. 
rzekomym odbiciem. W momencie opuszczenia jaskini przez Bodhidharmę Shaolin został poświęcony szerzeniu działalności sekty chan.

Da Mo w swojej doktrynie zawarł kwintesencję chińskiej filozofii. Zakłada ona samodoskonalenie się poprzez głęboką medytację w pozycji siedzącej. Większość dnia mnichów upływała na takiej właśnie medytacji. Sposób praktykowania buddyzmu według zasad chanu został zaadaptowany do tradycyjnej chińskiej psychologii ${ }^{2}$. Dlatego pozostał popularny przez stulecia, podczas gdy inne przeżywały wzloty i upadki. Szczyt popularności sekty chan przypada na rządy dynastii Tang (618907). Wtedy to większość mieszkańców klasztoru poświęciła się studiowaniu tej doktryny. Ustanowiło to solidny fundament, który pozwolił przedstawić ją całemu światu. To właśnie buddyzm przyczynił się do powstania najstarszej sztuki walki.

Chińskie sztuki walki były rozwinięte, zanim Bodhidharma trafił do Shaolin. Trenowano je w celach typowo wojennych. Doniesienia mówią o dwóch uczniach Ba Tuo - Hui Guang i Seng Chou, którzy byli wytrawnymi wojownikami kung fu. Ich styl jednak nie był szeroko znany. Przekaz historyczny potwierdza, że Hui potrafił kopnąć lotkę pięć razy pod rząd, stojąc na obrzeżu studni. Z kolei Seng Chou przepędził dwa tygrysy, będąc uzbrojony jedynie w lancę. Chan Zhang Gun to broń osadzona na długim drzewcu, zakończona charakterystycznym kulistym motywem. Jest to typowy atrybut przeora świątyni buddyjskiej³

Pomimo wcześniejszych wzmianek o istnieniu sztuki walki z Shaolin dopiero Bodhidharma ją rozwinął i usystematyzował. Spośród wielu opowieści dotyczących genezy kung fu/wushu najbardziej wiarygodna wydaje się ta, która mówi o skostniałych, ścierpniętych kończynach i zasypiających podczas medytacji mnichach. Widząc to, Bodhidharma stwierdził, że należy zrobić coś, aby podnieść poziom sprawności i poprawić krążenie u swoich pobratymców. W tym celu stworzył zestaw ćwiczeń fizycznych o nazwie „18 rąk Luohan”. Forma tych ćwiczeń z czasem ewoluowała, aż wykształciło się shaolińskie tradycyjne wushu, które możemy podziwiać obecnie. Inne podania mówią o konieczności obrony przed atakami dzikich zwierząt, jeszcze inne o obronie samego klasztoru. Te ostatnie podania wydają się naturalną konsekwencją rozwoju ćwiczeń Da Mo.

Shaolin Luohan Shi Ba Shou - 18 rąk Luohan to najstarszy klasztorny system tradycyjnego wushu, stworzony przez mnichów jeszcze przed przybyciem Bodhidharmy. Jak wspomniano, podróżujący mnisi bardzo często byli narażeni na ataki ze strony rabusiów. Można powiedzieć, że styl ten ma tyle lat co sam klasztor. Stworzone przez Bodhidharmę 18 rąk Luohan to zestaw ćwiczeń qigong, który miał witalizować medytujących mnichów. Obecnie shaolin jest stylem samym w sobie. Według mistrza Shi De Honga kwintesencja shaolińskiego wushu to: Luohan quan (formy pięści luohan, m.in. Xiao Luohan Quan, Da Luohan Quan, Luohan Quan, Xin

\section{Ibidem.}

3 Ibidem. 
Luohan Quan), Da i Xiao Hong Quan (mała i duża forma czerwonej pięści), Tongbei Quan (sztuka wykorzystania tzw. jingu), Pao Quan (wybuchowy shaolin), Luohan Shi Ba Shou (18 rąk Luohan - 18 form składających się na całość tego stylu). Do tego dochodzą formy z bronia, których jest 18 rodzajów. Najbardziej podstawowymi sa: gun (kij - korzeń), qian (włócznia - król), jian (miecz - dżentelmen), dao (szabla dowódca) ${ }^{4}$. Dzisiejsze usystematyzowanie sztuki walki ze świątyni Młodego Lasu jest wynikiem wielu przemyśleń oraz wymiany doświadczeń mnichów i ekspertów różnych stylów walki.

Prawda jest również, że czerwone mury klasztoru nie oddzielały życia klasztornego od tego, co działo się poza nim. Pomoc lokalnej ludności i udzielanie schronienia uchodźcom towarzyszyły religijnym obrzędom klasztornej braci. Wiadomo też, że istnieli mnisi wojownicy lub mnisi żołnierze, którzy początkowo mieli bronić klasztorne włości przed wszelkimi bandytami. Pod koniec panowania dynastii Sui i na początku rządów dynastii Tang generał Wang Shichong zebrał ogromną armię, aby zdetronizować cesarza Tang, ustanawiając tym samym własne rządy pod nazwą Królestwo Zheng. Swojego bratanka uczynił generałem i wysłał go wraz z armią do wioski Baigu w celu uprowadzenia Li Shimina - cesarskiego syna. W 620 r. Li Shimin, czując, że znajduje się w niebezpieczeństwie, wezwał do pomocy 13 mnichów. Wśród nich byli Zhi Cao, Hui Yang i Tan Zong. Złapali oni generała Wanga Renze, co miało ogromny wpływ na zjednoczenie całej dynastii Tang. Książę Li został intronizowany jako cesarz Tang. Za pomoc mnisi zostali nagrodzeni 40 ha ziemi, a mnich Tan Zhong został wielkim generałem armii cesarskiej ${ }^{5}$.

W epoce Pięciu Dynastii i Dziesięciu Królestw (907-965) Fu Ju, ówczesny przeor klasztoru Shaolin, zaprosił ekspertów z 18 szkół walki celem wymiany doświadczeń. Przebywali oni w klasztorze przez 3 lata, w ciagu których zredagowali Podrecznik boksu shaolinskiego. Z kolei za panowania dynastii Jin (1115-1234) i Yuan (1279-1227) kolejni mistrzowie Bai Yufeng i Li Sou trafili do świątyni buddyjskiej. W wyniku tych wizyt na podstawie 18 rąk Luohan i boksu imitacyjnego 5 zwierząt, do których należą smok, lampart, wąż, tygrys i żuraw, stworzono ponad 70 form shaolińskiego kung fu.

Praktyka wushu z Shaolin, jak przystało na sztukę walki, nie jest ograniczona przestrzenią. Mówi się, że jej praktyk potrzebuje tyle miejsca, ile zajmuje leżący wół, niezależnie od pogody czy używanej broni lub jej braku. Charakterystyczne dla technik tego stylu, jak również przynależnych do niego układów formalnych jest to, że wykonywane są one w linii prostej. Podczas ataku pięści powinny generować wirująca elastyczną siłę, a oczy powinny być skupione na przeciwniku, by odczytać jego intencje. Ciało powinno być gibkie, a stopy lekkie jak piórko i ciężkie jak góra Taishan.

4 Geng Zhi, Liang Yiquan, Shaolin Martial Arts, Beijing 1987.

5 Ibidem. 
Metoda walki z Shaolin łączy w sobie tzw. akcje twarde i miękkie, zewnętrzne i wewnętrzne z wykorzystaniem energii qi. Strategię walki można opisać następująco: „Bądź szybki jak błyskawica. Wycofuj się jak wiatr. Poruszaj głową jak falujące morze. Miej postawę solidną jak głaz. Ciałem poruszaj niczym lecący smok. Ręce winny być jak spadające gwiazdy. Wszystkie ruchy wypływają z umysłu i współgraja z naturą walczącego. Ataki są twarde i silne, ale nie sztywne. Mają być jak trzcina na wietrze, zmieniając jedną formę ataku na inną. Ataki winny zawierać markowanie i element zaskoczenia. Broniąc się bądź jak niewiasta, ale nie słaby, atakuj jak tygrys"'.

Gwałtowny rozwój zarówno teorii, jak i praktyki tradycyjnych sztuk walki z użyciem broni dokonał się za czasów panowania dynastii Ming. Pierwszą książką z tego okresu jest Sztuka broni autorstwa mnicha Hong Chuanzenga. Za panowania cesarza Wangli świecki uczeń imieniem Cheng Zongyou po 10 latach ćwiczenia posługiwania się kijem napisał książkę Wstęp do shaolinskiego kija. Techniki wushu z tego okresu były w powszechnym użyciu podczas bitew i wojen. Generał Yu Dayou za panowania cesarza Jianjing nie tylko wykorzystał sztukę walki kijem, której nauczył się, będąc uczniem świątyni, ale również rozwinął ją dodając do bogatego zestawu nowe techniki. Po wizycie w Shaolin Wen Xianfeng tak opisał to, co tam zobaczył: „sześćdziesięciu mnichów trenujących wushu, niektórzy techniki ręczne, inni z użyciem szabli, biczy czy halabard".

Na przestrzeni wielu lat i konfliktów shaolińskie kung fu było rozwijane i udoskonalane. Można powiedzieć, że z czasem dojrzewało niczym najbardziej wytrawne wino. Za panowania dynastii Ming (1368-1644) rząd był podatny na wpływy najeźdźców spoza Państwa Środka. W tamtym czasie kilka tuzinów mnichów wojowników zostało wysłanych do obszarów granicznych. Za panowania cesarza Jiajinga Yue Kong poprowadził 30 mnichów w zwycięskiej bitwie pod Songjiang. Niestety, później podczas próby ocalenia cywilów zostali zabici. Istnieją również opowieści o przeorze Xiao Shan, który w imieniu rządu trzykrotnie prowadził mnichów do walki z zagranicznymi najeźdźcami.

W 1644 r. Mandżurowie ustanowili dynastię Qing, która nie została zaakceptowana przez naród. Chciano ją obalić i przywrócić panowanie Mingów. Faworyzowany przez nich klasztor Shaolin był siła, której obawiali się Qingowie. Wydali oni zakaz (pod karą śmierci) uprawiania sztuk walki. Spowodowało to wędrówkę mnichów, którzy później powrócili do świątyni z większą wiedzą i umiejętnościami

Pomimo zakazu pod koniec dynastii Qing powszechnie praktykowano kilka rodzajów boksu z Shaolin. Rozwijano umiejętności pod osłoną nocy i za zamkniętymi

${ }^{6}$ Liu Haichao, Shaolin Gong-Fu. A Course in Traditional Forms, Henan Scientific and Technical Publishing House [b.m.] 1994, s. 2-4.

7 The story of Shaolin, „KungFu Magazine.com”, http://www.kungfumagazine.com/magazine/ article.php?article $=90$ (dostęp: 15.08. 2016). 
drzwiami. Jednym z legendarnych dowodów, który świadczy również o determinacji mnichów, aby ich sztuka nie zaginęła, są wgłębienia w kamiennej podłodze w Pawilonie Tysiąca Buddów. W tym czasie również położono duży nacisk na praktykę ćwiczeń qigong, czyniąc tym samym z ciała silniejszą i twardszą broń.

Zdając sobie sprawę z potęgi shaolińskich mnichów, rozkazano spalenie świątyni. Kolejny raz ogień podłożono z rozkazu dowódcy Shi Yousan kilka wieków później w 1928 r. Ogień palił się przez 40 dni, strawił wiele rękopisów dotyczących sztuki walki z Shaolin, ponadto wiele reliktów tamtego okresu zostało bezpowrotnie utraconych. Kolejną mroczną kartą w historii sztuki walki z Młodego Lasu była rewolucja kulturalna, której jednym z zadań było wyzbycie się tradycji. Działająca w tym czasie Czerwona Gwardia niszczyła pomniki, jak również przeprowadzała egzekucje niepoprawnych politycznie obywateli. Jednym z azyli dla takich osób był właśnie klasztor Shaolin.

Obecnie rola klasztoru sprowadza się głównie do funkcji atrakcji turystycznej i miejsca sakralnego. Treningi mnichów odbywają się, kiedy obiekt jest zamknięty lub w tylko im znanych miejscach w górach. Funkcję szkoleniową przejęło otwarte w 1987 r. Centrum Treningowe znajdujące się w sąsiedztwie samego klasztoru.

\section{Kung fu/wushu - sztuka walki i sport walki}

Powyższy krótki wstęp historyczny miał na celu podkreślenie praktycznie nierozerwalnego związku trzech czynników: samego klasztoru Shaolin, dziejów narodu chińskiego oraz kung fu/wushu. Zrozumienie historii i zagłębienie się w nią odróżnia sztuki od sportów walki. Tymczasem w wielu publikacjach traktujących o chińskich sztukach walki te dwa terminy są używane zamiennie.

Nie każdy zdaje sobie sprawę z tego, że obco brzmiący termin wushu tak naprawdę oznacza sztukę walki, którą w ubiegłym wieku promowali Bruce Lee czy Jackie Chan. W zachodnim świecie chińskie sztuki walki były znane pod nazwą kung fu. Przyglądając się znaczeniom poszczególnych zwrotów (wushu - sztuka walki, kung fu - ciężka i długotrwała praca), można dojść do wniosku, że oba sa poprawne. Nauka sztuki walki to długa, żmudna i ciężka praca. Można powiedzieć, że jest to niekończąca się droga samodoskonalenia. Z historycznego punktu widzenia termin kung fu jako ten o zabarwieniu mistycznym mógł zostać zamieniony na wushu za czasów rewolucji kulturalnej. To właśnie w jej wyniku powstało tzw. sportowe wushu. W nurcie tym wyróżniono konkurencje form i wolnej walki sanda. Krok taki miał na celu wyzbycie się tradycji z jednoczesna próbą zachowania specyfiki i kolorytu chińskich sztuk walki. Tutaj pojawił się kolejny sposób nazewnictwa, otóż sportowy nurt nazwano wushu, natomiast tradycyjny kung fu. Tak naprawdę wyróżnia się xiandai lub jingsai wushu (współczesne lub sportowe wushu) oraz chuantong lub minjian 
wushu (tradycyjne lub ludowe wushu). Pomimo to wiele szkół tradycyjnych chińskich sztuk walki nie tylko w Polsce, ale i na świecie używa w swojej nazwie kung fu. Jeśli wziąc pod uwage znaczenie tego zwrotu i dodać do niego nazwę stylu, takie podejście wydaje się jak najbardziej poprawne.

Opanowanie tradycyjnego stylu wymaga od ćwiczącego dużo wysiłku, pracy i zaangażowania. Trening tradycyjny w porównaniu z typowo sportowym dodatkowo zawiera takie elementy, jak: utwardzanie, qigong, taichi, zastosowania bojowe praktykowanych form. Tylko taki trening, w którym zawarte są powyższe elementy, można uznać za tradycyjną sztukę walki. Niestety, w wielu szkołach, klubach czy sekcjach ćwiczone są tylko układy ruchów (formy) bez dogłębnego ich studiowania i zrozumienia.

Podsumowując, mimo że od rewolucji kulturalnej minęło już wiele czasu, nurt tradycyjny nazywa się kung fu, a nurt sportowy - wushu. W wielu publikacjach z kolei zwroty te są używane zamiennie lub razem jako kung fu/wushu. Wydaje mi się, że ostatnia opcja jest najtrafniejsza z uwagi na to, że trenując sztukę walki, można również brać udział w rywalizacji sportowej.

W każdej dyscyplinie sportowej, a za taką należy uważać również kung fu/wushu, ostatecznym celem jest osiagnięcie mistrzostwa w wyniku rywalizacji. Oczywiście są też ćwiczenia rekreacyjne, a ćwiczący w ten sposób nie biorą udziału w zawodach sportowych. W przypadku sztuk walki trening jest na tyle wszechstronny, że ćwiczący może rozwijać się zarówno dla samego siebie, jak i zajmować się kariera sportowa. Dodatkowo w sztukach walki wskazane jest zaznajomienie się z historią ćwiczonego stylu oraz z linią przekazu, gdyż to właśnie obok specyficznych metod treningowych różni sztuki walki od sportów walki. Kolejnym wyróżnikiem chuantong wushu są wierszowane przekazy technik lub bardzo kwieciste, wręcz mitologiczne nazwy poszczególnych technik. Warto przytoczyć kilka przykładów nazw technik z formy taiji 24 ruchów: rozczesywanie grzywy dzikiego konia, biały żuraw rozkładający skrzydła, ręce falujące jak chmury, praca na czółenku ${ }^{8}$ W klasztornym stylu 18 rąk Luohan z kolei można znaleźć 18 następujących podstawowych technik: pojedyncza krokiew, napinanie łuku, działo zamontowane na belce, mnich uderzający w dzwon, zręczna igła, przenoszenie młota ponad ciałem, łokieć feniksa, ścinanie pnia, mnich wywarzający drzwi, złoty hak, omiatanie nogi, kopnięcie w krocze, kopnięcie kaczki mandarynki, orzeł chwytający za gardło, przenoszenie kosza na ramieniu, skręcanie jedwabnej nici, smok przechwytujący dłoń, mnich wiążący tygrysa'. Takich przykładów jest bardzo wiele. Praktycznie każda z form tradycyjnego Shaolin wushu, ręczną lub z bronia, cechuje barwne nazewnictwo zawartych w niej technik.

8 A. Braksal, Tai chi chuan - chinska sqtuka walki, medytacji $i$ qdrowia, Warszawa 1992.

9 Cai Longyun, The Eighteen Arhat Methods of Shaolin Kungfu, Hong Kong 1986. 


\section{Style imitatywne}

Każde zwierzę - zarówno duże, takie jak lew czy tygrys, jak i małe, jak mrówka czy modliszka - walczy na swój sposób o przeżycie. Praktycy buddyzmu chan z klasztoru Shaolin włączyli tzw. prawo do przetrwania do swojego systemu walki, a ściślej mówiąc - do form stylowych. Jak w żadnej innej sztuce walki techniki imitujące zachowanie poszczególnych zwierząt pomagały w pokonywaniu i zaskakiwaniu przeciwników. Styl małpy, bazujący na ruchach i zachowaniu tego zwierzęcia, wymaga ponadprzeciętnej zwinności. Nadaje się on zarówno do obrony, jak i ataku. Techniki żurawia są szybkie jak błyskawica, smok wyprzedza intencje przeciwnika, wąż dzięki swej niesamowitej zwinności atakuje punkty witalne, tygrys wykorzystuje swoją siłę fizyczna, a boks stylu lwa pokonuje wszelki opór swą dzikością i brutalnością. Zatem to warunki fizyczne adepta predysponowały go do praktyki określonego stylu walki.

Perełką w chińskich sztukach walki jest styl pijanego mnicha. Był on używany zarówno do walki, jak i w celu utrzymania zdrowia. Dlatego chciałbym poświęcić mu nieco więcej miejsca. Osoba ćwicząca zachowuje się tak, jakby była pod wpływem alkoholu, zachowując przy tym trzeźwy umysł. Wachlarz charakterystycznych ruchów obejmuje zataczanie, akrobatykę, pady, wyskoki, a wszystko to na granicy utraty równowagi. Akcje techniczne mają za zadanie zmylić przeciwnika i uśpić jego czujność. Bojowe techniki ukryte są w niewinnie i niejednokrotnie śmiesznie wyglądających ruchach, dlatego też walczący w ten sposób podkreślali jego niesamowita skuteczność ${ }^{10}$.

Cai Longyun i Shao Shankang w swojej książce w pięciu punktach opisują zasady techniczne tego stylu walki ${ }^{11}$.

Po pierwsze, trenując styl pijanego, trzeba zaadaptować się do warunków i stylu zachowania pijanego człowieka. Wszystkie pijane akcje, na które składają się uskoki, wychylenia, obroty, zmiany położenia, przemieszczanie, wykonuje się w myśl zasady: „gdy atak nadchodzi ze wschodu, oddajesz na zachód, wskazujesz zachód, ale uderzasz na wschód, markujesz atak tutaj, ale eksplodujesz tam - wynika to z błędu przeciwnika”. Z tego względu, trenując zuijiuquan, należy rozumieć znaczenie i znać zastosowanie poszczególnych ruchów (czy są to odskoki, czy uniki, zbliżanie się czy ucieczka, napieranie czy podążanie, markowanie czy przejmowanie). Pijana forma pozostaje tylko ruchem, jeśli nie wydobędzie się esencji w postaci umiejętności bojowych, dlatego ćwiczenie form i ich aplikacji bojowych powinno stanowić nierozerwalną całość. Niedopuszczalnym błędem jest koncentrowanie się tylko na pijanych ruchach, odrzucając umiejętności walki. Pijany ruch jest efektem momentu pędu, nie odwrotnie. Pięści powinny być ukryte pod osłona pijaństwa (charakterystyczny układ dłoni), a techniki walki - na tyle pijackie, na ile to możliwe.

10 „Kung Fu Qigong Magazine”, Special Issue, January 2000.

11 Cai Longyun, Shao Shankang, Zuijiuquan: A Drunkard's Boxing, Hong Kong 1997. 
Po drugie, w trakcie treningu stylu pijanego trzeba ściśle przestrzegać jego zasad. Chwiejne kroki i taka sama praca ciała łatwo mogą powodować niestabilne jego ułożenie i zaburzać pracę stóp. W chińskim tradycyjnym wushu dużą wage przywiązuje się do pracy rąk, oczu, tułowia czy stóp, a na poszczególnych etapach treningu należy przestrzegać określonych reguł, aby poruszające się ciało stanowiło jedność. Podczas praktyki zuijüquan pracować musi całe ciało, dodatkowo nie mogą być widoczne jakiekolwiek naprężenia czy sztywność. W myśl chińskiej dewizy związanej ze sztukami walki należy przyłożyć siłę wtedy, kiedy jest potrzebna i tyle, ile wymaga tego sytuacja - ani więcej, ani mniej. Bez stosowania powyższych wskazówek styl nie będzie pijany.

Po trzecie, podczas praktyki zuijiuquan trzeba wydobyć wigor i siłę ze swoich kości i mięśni. Ciało powinno być zwiewne i delikatne, a twardość i solidność ruchów będą wtedy oczywiste. W każdym ruchu i pozycji należy perfekcyjnie panować nad ścięgnami, tułowiem i kończynami, tak aby ruchy były silne wewnętrznie tak jak podczas wyciagania miecza lub naciagania łuku. Pojęcie siły w stylu pijanego jest inne niż w pozostałych stylach, gdyż jest ona eksponowana wewnętrznie, a nie zewnętrznie. Ruchy są mocne, ale delikatne niczym igła znajdująca się w bawełnianej kuli.

Po czwarte, w stylu pijanego wszystkie akcje muszą być wyprowadzane świadomie. Wymagane jest nie tylko pokazanie umiejętności walki, ale również zachowanie się wskazujące na spożycie alkoholu. Tylko wówczas, gdy stan umysłu i ciało staną się jednym, możliwe będzie pokazanie swoich umiejętności zuijiuquan.

Po piąte, w stylu pijanego rzuty i upadki wynikają z „pijanego momentu ruchu”. Sztuka padania ma również uodpornić organy wewnętrzne na stłuczenia i obicia. Kontrolowana utrata równowagi powoduje dezorientacje przeciwnika. Kiedy jest się na ziemi, należy wykorzystać techniki parterowe do obezwładnienia go.

Kiedy trenowałem styl pijanego mnicha podczas mojego pobytu w Chinach w 2000 r., mnich Shi De Qi zwracał uwage na nietypowe zastosowania bojowe niektórych technik. Były to uderzenia praktycznie każdą częścią ciała. Są to akcje, których nie spodziewa się większość trenujących sztuki walki.

Oprócz wymienionych istnieje wiele innych styli naśladowczych, jak gou quan styl psa, xiong quan - niedźwiedzia, tang lang quan - modliszki, pao quan - lamparta itd. Osoba trenująca i walcząca jednym z nich powinna oddać charakter i ducha konkretnego zwierzęcia lub w przypadku stylu pijanego mnicha wypracować szybkie, na pozór pozbawione ładu i równowagi techniki. Samo szkolenie jest procesem niezwykle wymagającym ze względu na wspomnianą wcześniej wieloaspektowość treningu.

Jak widać, trenowanie kung fu/wushu jako sztuki walki wydaje się nie mieć końca. Swoim uczniom często powtarzam dewizę: „Nigdy nie jest tak dobrze, żeby nie mogło być lepiej”. Odnosi się to zarówno do wykonywania form lub pojedynczych technik, jak i do samej walki. Postawa taka oraz świadomość wysiłku i pracy, jakie trzeba włożyć w naukę sztuki walki, sprawdza się też w życiu codziennym, w którym zmagamy się z wieloma przeciwnościami. Poprawna praktyka wushu nie tylko rozwija, ale też uczy, co znaczy „powstać jak feniks z popiołu”. W tradycyjnym podejściu 
do treningu nie ma wiele miejsca na pochwałę. Tylko ten, kto potrafi znieść krytykę, pohamować gniew z niej wypływający, okazać skromność w odpowiednim momencie, dojdzie na szczyt i zbliży się do realizacji swoich marzeń. W świecie, w którym większość oczekuje odpowiedzi i wyjaśnień wprost, prowadzenie tradycyjnej szkoły walki jest niezwykle trudne. Oczekuje się tutaj własnych poszukiwań oraz dużego wkładu i zaangażowania w poznawaniu i późniejszym zrozumieniu przekazywanego materiału. Mistrzowie kung fu mówią, że aby zrozumieć tradycyjne wushu, należy być Chińczykiem. Jest w tym dużo prawdy, ponieważ dzieje Chin i chińska sztuka walki to jeden organizm. Jedno nie istnieje bez drugiego. Pomimo że moim nauczycielem jest osoba, która wushu uczyła się od mistrza chińskiego, dopiero po treningach w Shaolin zrozumiałem, czym jest shaolin wushu. To coś więcej niż sztuka walki, to historia, która powoduje, że osoba wnikliwa, słuchająca i poszukująca będzie w stanie walczyć każdego dnia. Walka ta toczy się nie tylko na ringu. Ważna jest świadomość, że zawody sportowe to jedynie sprawdzian umiejętności ujętych w regulaminy i zasady, których sztuka walki nie potrzebuje.

\section{SUMMARY}

\section{SHAOLIN KUNG FU/WUSHU: A TREASURE OF THE CHINESE NATION}

The history of Chinese martial arts is both turbulent and interesting as the history of China itself. They played a crucial role during turning points on many occasions. This treasure of national importance almost vanished due to the events of the Cultural Revolution. The article presents a shortened history of the traditional Shaolin kung fu. The role of Bodhidharma - an Indiam Buddhist who settled in a temple is also explained. Additionally, there is an attempt of explaining the terminology, precisely kung fu or wushu, what is correct? Also the characteristics of Shaolin martial arts are given. All is concluded with the description of imitative boxing and its technical principles. Namely, they are the Five Animals style including the crane, tiger, leopard, snake and dragon, mantis, monkey and others. A very peculiar example of this kind of styles is the drunken one. This technique is explained in details. When dealing with traditional wushu one must be aware of the fact that it is an endless and hard way of self-improvement and development. And the final success is not only connected with sport achievements. 